Article

\title{
Detection of Cyanotoxins, $\beta$ - $N$-methylamino-L-alanine and Microcystins, from a Lake Surrounded by Cases of Amyotrophic Lateral Sclerosis
}

Sandra Anne Banack ${ }^{1}$, Tracie Caller ${ }^{2, \dagger}$, Patricia Henegan ${ }^{3, \dagger}$, James Haney ${ }^{4, \dagger}$, Amanda Murby ${ }^{4}$, James S. Metcalf ${ }^{1}$, James Powell ${ }^{1}$, Paul Alan Cox ${ }^{1}$ and Elijah Stommel ${ }^{3, *}$

1 Institute for Ethnomedicine, PO Box 3464, Jackson, WY 83001, USA;

E-Mails: sandra@ethnomedicine.org (S.A.B.); james@ethnomedicine.org (J.S.M.); jpowell@ethnomedicine.org (J.P.); paul@ethnomedicine.org (P.A.C.)

2 Cheyenne Regional Medical Group, Cheyenne, WY 82001, USA;

E-Mail: tracie.a.caller@dartmouth.edu

3 Department of Neurology, Dartmouth-Hitchcock Medical Center, Lebanon, NH 03756, USA; E-Mail: patricia.1.henegan@hitchcock.org

4 Department of Biological Sciences, University of New Hampshire, Durham, NH 03824, USA; E-Mails: jim.haney@unh.edu (J.H.); amurby@unh.edu (A.M.)

$\dagger$ These authors contributed equally to this work.

* Author to whom correspondence should be addressed; E-Mail: elijah.w.stommel@ hitchcock.org; Tel.: +1-603-650-8615; Fax: +1-603-650-6233.

Academic Editor: Luis M. Botana

Received: 19 November 2014 / Accepted: 21 January 2015 / Published: 29 January 2015

\begin{abstract}
A cluster of amyotrophic lateral sclerosis (ALS) has been previously described to border Lake Mascoma in Enfield, NH, with an incidence of ALS approximating 25 times expected. We hypothesize a possible association with cyanobacterial blooms that can produce $\beta$ - $N$-methylamino-L-alanine (BMAA), a neurotoxic amino acid implicated as a possible cause of ALS/PDC in Guam. Muscle, liver, and brain tissue samples from a Lake Mascoma carp, as well as filtered aerosol samples, were analyzed for microcystins (MC), free and protein-bound BMAA, and the BMAA isomers 2,4-diaminobutyric acid (DAB) and $N$-(2-aminoethyl)glycine (AEG). In carp brain, BMAA and DAB concentrations were $0.043 \mu \mathrm{g} / \mathrm{g} \pm 0.02 \mathrm{SD}$ and $0.01 \mu \mathrm{g} / \mathrm{g} \pm 0.002 \mathrm{SD}$ respectively. In carp liver and muscle, the BMAA concentrations were $1.28 \mu \mathrm{g} / \mathrm{g}$ and $1.27 \mu \mathrm{g} / \mathrm{g}$ respectively, and DAB was not
\end{abstract}


detected. BMAA was detected in the air filters, as were the isomers DAB and AEG. These results demonstrate that a putative cause for ALS, BMAA, exists in an environment that has a documented cluster of ALS. Although cause and effect have not been demonstrated, our observations and measurements strengthen the association.

Keywords: $\beta-N$-methylamino-L-alanine (BMAA); amyotrophic lateral sclerosis (ALS); cyanobacteria; aerosols

\section{Introduction}

It is probable that one or more environmental toxins contribute to the etiology of sporadic Amyotrophic Lateral Sclerosis (ALS), most likely interacting with underlying genetic susceptibility factors $[1,2]$. A neurotoxin produced by cyanobacteria, $\beta-N$-methylamino-L-alanine (BMAA) has been implicated as a potential environmental risk factor for ALS [3-5]. Cyanobacteria are ubiquitous throughout all ecosystems, most commonly in marine and freshwater environments [6] and are well-known to produce toxins that have human health implications [7-9].

Following the Second World War, a high frequency of ALS and ALS-like conditions (ALS/Parkinsonism dementia complex (ALS/PDC)) was observed in the Marianas Islands, mainly in Guam, where in the early 1950s it was estimated to be $50-100 \times$ higher than in industrialized nations [10-13]. Initial research suggested that cycad seeds, a dietary staple used by the indigenous Chamorro people to make flour, might be the environmental source of interest [14-17]. BMAA, derived from cyanobacteria existing symbiotically in the coralloid roots of Cycas micronesica [18,19], was discovered in the cycad seeds [18,20,21]. Further investigation demonstrated that BMAA is mainly concentrated in proteins and was consumed by the Chamorros through multiple dietary sources, including cycad flour, flying foxes (a type of fruit bat), and other animals that fed on cycad seeds, leading to biomagnification through the food chain [5,19,22-24]. Accumulation of BMAA in the brains of Chamorro patients with ALS/PDC as well as brains from North American ALS, Parkinson's disease, and Alzheimer's disease, but not Huntington's disease, further supported this hypothesis [3,5,19,25]. The decrease of both cycad seeds and flying foxes in the Chamorro diet correlated with the dramatic decline of ALS in Guam over the subsequent five decades to incidence rates similar to the rest of the world [26-28]. A link between BMAA and ALS outside of Guam has not definitively been established. Epidemiologic studies of migrants both to and from Guam also suggested a lag period of years to decades between exposure and disease development, which makes epidemiology studies of environmental factors very difficult [29-32]. Emigrants from Guam, who lived on Guam during their childhood and adolescence for at least 18 years, developed ALS one to 34 years after leaving the island suggesting a possible latency period of more than 30 years [29-31]. Likewise, Filipino residents in Guam developed ALS one to 29 years after migrating to the island [32]. These latency periods are consistent with the time-dependent latency of deployed Gulf War veterans from the 1990-1991 Persian Gulf war who had higher incidence rates of ALS starting 5 years after exposure and tailing off after a 5 to 10 year period following the war $[33,34]$. Those deployed to the Gulf had ALS incidence rates two-fold higher than 
veterans who were trained at the same time but were not deployed [35-37]. These observations have implications for the development of an animal model related to chronic exposure to the neurotoxin.

In 2009, we described a number of cases of amyotrophic lateral sclerosis (ALS) from Enfield, NH who lived in proximity to Lake Mascoma, a lake known to have a history of cyanobacterial blooms, documented by a state monitoring program. After adjusting for underlying population density, our epidemiology spatial analysis results confirmed an incidence of sporadic ALS that was approximately 10-25 times the expected incidence of 2/100,000/year [38]. We identified nine ALS patients who lived on or near Lake Mascoma and adjoining Crystal Lake (on average less than 0.15 miles from the shore) for a minimum of nine years, and were diagnosed between the years 1990 and 2007. One patient was diagnosed in 1990; all other patients were diagnosed between the years 2000-2006. We have diagnosed one more patient in 2013 who has lived directly on Lake Mascoma for the last 10 years. There also appeared to be a spatial association between cyanobacterial blooms and ALS in NH [38,39]. Since population density was corrected for using ArcGIS, the distribution of ALS cases was not thought to be an artifact of population density [38]. Understandably, there has been some criticism pertaining to our lack of published data regarding the presence of BMAA in Lake Mascoma. Surface water samples collected in 2008 at the time of the spatial analysis study contained no detectable BMAA concentrations. This absence could be a function of the concentration of cyanobacteria (no significant cyanobacterial blooms were observed on Lake Mascoma that year), or a function of whether the bloom material is actively making BMAA. It has been shown that BMAA is not continuously produced by cyanobacteria, but likely depends on external factors [40]. The actual role of BMAA and the timing of its release are not well known. We hypothesized that in the absence of active blooms, sampling a relatively large fish or other biospecimens from Lake Mascoma might reveal a reservoir (the equivalent of the flying fox in Guam) for BMAA. Our objective was to analyze a 15-18 year old large carp (Cyprinus carpio) caught on the southeast end of the lake by a local resident. Lake Mascoma contains a population of large carp that were inadvertently introduced into the lake during the 1938 hurricane that devastated New England. The carp were a source of food for the Shakers who lived on the lake and had small, man-made ponds near Lake Mascoma. These carp ponds were washed out during the hurricane spilling the carp into Lake Mascoma. Some of these bottom-feeding carp are now huge, weighing up to 100 pounds. Most carp eat aquatic plants, insects, crayfish, dead fish, mollusks such as freshwater clams, and nuts that fall from trees into the water $[41,42]$. They tend to live on the bottom but occasionally surface. We chose to analyze tissue for BMAA as well as microcystin, a known hepatotoxin for which multiple detection methods exist. In addition, we have been concerned that aerosolization of cyanobacteria and its toxin BMAA may serve as a means of human exposure [43]. Therefore, filtered aerosol samples were collected at lakeside and also analyzed for the presence of cyanobacteria and its toxins, as the majority of ALS patients lived in an area downwind from the dominant air flow directions.

\section{Results and Discussion}

\subsection{Results}

BMAA was identified within the Lake Mascoma carp brain, liver, and muscle tissues, providing evidence of the presence of BMAA in the Mascoma Lake food web (Figure 1, Table 1). The toxic BMAA 
isomer 2,4-diaminobutyric acid (DAB) [44] was also identified in the carp brain, but not in the other fish tissues. BMAA and DAB are distinguished by both retention times $(\mathrm{BMAA}=4.8 \mathrm{~min} ; \mathrm{DAB}=5.0 \mathrm{~min}$, Figure 1) and ion ratios (Table 1; comparable DAB ratios are as follows: $\mathrm{m} / \mathrm{z} 289 / 171=4.0$; $\mathrm{m} / \mathrm{z} 119 / 171=6.0)$.

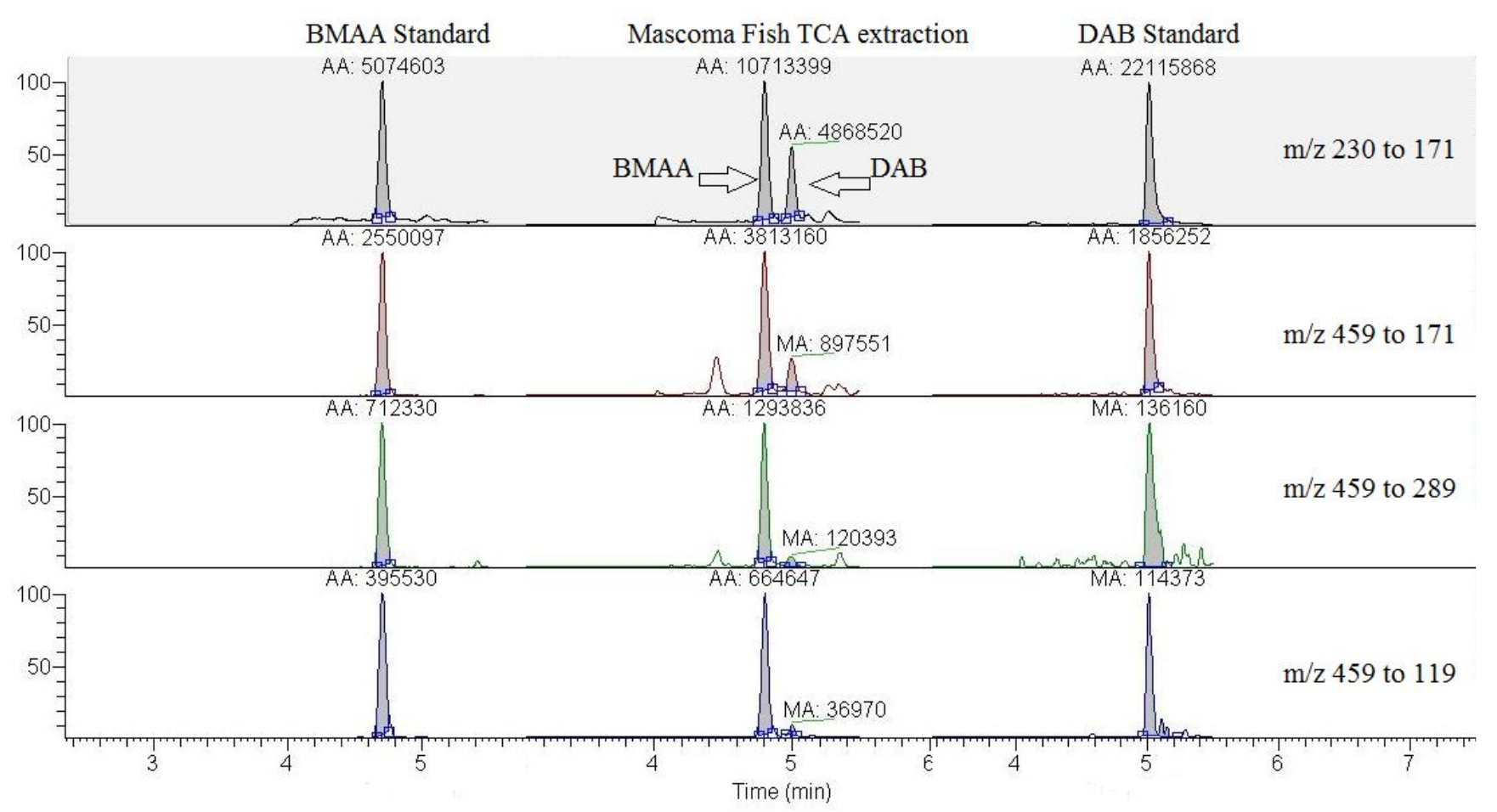

Figure 1. Representative LC-MS/MS chromatogram from Lake Mascoma carp brain with $\beta$ - $N$-methylamino-L-alanine (BMAA) (4.8 $\mathrm{min})$ and 2,4-diaminobutyric acid (DAB) (5.0 min) standards for comparison.

Table 1. Concentration of BMAA in Lake Mascoma carp along with the LC-MS/MS ion ratios as compared to BMAA standards.

\begin{tabular}{|c|c|c|c|c|c|}
\hline Tissue & $\begin{array}{l}\text { Number of } \\
\text { replicates } \\
\text { examined }\end{array}$ & $\begin{array}{c}\text { BMAA total } \pm \text { SD } \\
(\mu \mathrm{g} \text { BMAA/g sample) }\end{array}$ & $\begin{array}{c}\text { DAB total } \pm \text { SD } \\
(\mu \mathrm{g} \text { DAB/g sample) }\end{array}$ & $\begin{array}{c}\text { Ratio of } m / z 289 / 171 \\
\text { from parent } m / z 459 \\
\text { at retention time } \\
\text { for BMAA }\end{array}$ & $\begin{array}{c}\text { Ratio of } m / z \text { 119/171 } \\
\text { from parent } m / z 459 \\
\text { at retention time } \\
\text { for BMAA }\end{array}$ \\
\hline Carp brain & 3 & $0.43 \pm 0.02^{\#}$ & $0.01 \pm 0.002^{\#}$ & $13.2 \pm 1.2 *$ & $28.9 \pm 0.6 *$ \\
\hline Carp liver & 3 & $1.28 \pm 0.03$ & ND & $12.5 \pm 0.8 *$ & $29.3 \pm 1.7 *$ \\
\hline Carp muscle & 1 & 1.27 & ND & 13.2 & 29.4 \\
\hline BMAA standard & 4 & - & - & $12.4 \pm 0.9$ & $31.0 \pm 1.6$ \\
\hline
\end{tabular}

\# Value reflects combined $\mathrm{TCA}+\mathrm{HCl}$ extractions for a total toxin value; * Pooled result of 3 replicate tissue samples with 3 injections each; not detected (ND).

Each air sample represents a separate filter collection which was analyzed simultaneously for BMAA, AEG, and DAB (Table 2). BMAA was identified in one Mascoma Lake air-filter sample but not in the Goose Pond sample (Table 2). Although BMAA was positively identified in this sample, the concentration was too low to quantify (method detection limit, MDL for BMAA $=48$ femtomoles; 
limit of quantification, $\mathrm{LOQ}$ for BMAA $=0.48$ picomoles). The positive BMAA identification was noted following the solid-phase extraction procedure. The concentration of DAB was above the LOQ (0.26 picomoles DAB) in only one sample (Goose Pond 5-24-10; $5 \mathrm{ng} \mathrm{DAB} / \mathrm{cm}^{2}$ of filter) and was above the MDL (26 femtomoles DAB) in three additional filter samples but as these three were below the LOQ they are reported only as present. $N$-(2-aminoethyl)glycine (AEG), a second toxic BMAA isomer found in natural samples [45,46], was found in the two samples from Mascoma Lake, but not in the samples from Goose Pond (Table 2). The concentrations of AEG were not quantified because only trace amounts were identified.

Table 2. Analysis of air filters from New Hampshire for $\beta$ - $N$-methylamino-L-alanine (BMAA), 2,4-diaminobutyric acid (DAB), and $N$-(2-aminoethyl)glycine(AEG).

\begin{tabular}{ccc}
\hline Toxin Analysis & Lake & Date \\
\hline ND & 2972 Goose Pond (cyano B + microcystin positive) & 4 July 2011 \\
DAB & 2973-1 Goose Pond (Background-No Blooms) & 24 May 2010 \\
DAB at 5 ng/cm filter $_{\text {AEG + DAB }}^{\text {2973-2 Goose Pond }}$ & 25 May 2010 \\
AEG + DAB + BMAA & Mascoma Lake 4 & $19-21$ September 2009 \\
\hline
\end{tabular}

We found no visible organisms on the air filters and the 16S DNA showed no evidence of un-degraded cyanobacterial DNA in the air filter samples (Figure 2). We note that Dr. Haney and colleagues at the University of New Hampshire routinely collect cyanobacteria on filters where an aerosol collector runs for as little as $3 \mathrm{~h}$ and is placed just over the surface of waterbodies known to have blooms [47]. A likely reason we found no cells on the filters in this study was our use of filters with coarse porosity $(100 \mu \mathrm{m})$, whereas the above mentioned aerosol studies utilize glass fiber filters with an effective pore size of $<1 \mu \mathrm{m}$, potentially allowing capture of cyanobacteria cells in the picoplankton range. It should be pointed out that the aerosol samples were essentially a point in time and likely do not represent peak concentrations of human exposure. A comprehensive survey of air filter collections is currently underway.

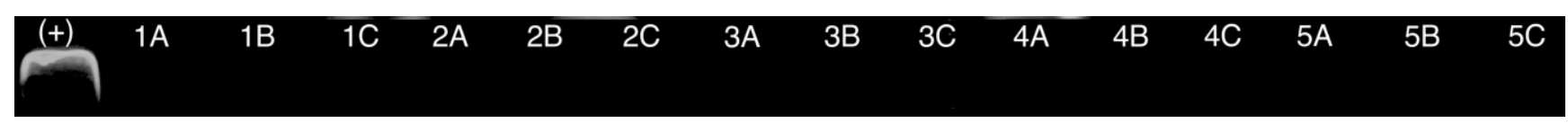

Figure 2. 16S PCR analysis of air filter samples, to assess cyanobacterial DNA. Dilutions of each sample were run $1 \times(\mathbf{A}), 1 / 10(\mathbf{B}), 1 / 100(\mathbf{C})$. Commercial Spirulina was used as a positive cyanobacterial control. 1, 2792 Goose Pond; 2, 2973-1 Goose Pond; 3, 2973-2 Goose Pond; 4, Mascoma Lake 4; 5, Mascoma Lake 5.

Microcystin was not detected in either the carp muscle or the kidney tissue, however, liver samples (analyzed in triplicate from each organ) had detectable concentrations of MC measuring 5.9, 6.3 and $6.3 \mathrm{ng} \mathrm{MC/g}$ liver wet weight. The MC concentrations reported here were extracted with freeze-thaw methods in water and represent extractable MCs rather than total MCs (protein-bound plus free MC). 


\subsection{Discussion}

These results show that there is BMAA, DAB, AEG, and MC in biospecimens acquired from Lake Mascoma, a lake with a remarkably high incidence of ALS in the direct vicinity [38]. Presumably these toxins result from the presence of cyanobacteria; other potential sources include diatoms or toxin reservoirs stored in the lake [48]. People living near cyanobacterial blooms may be exposed to BMAA and other cyanotoxins through recreation, dietary ingestion, or aerosolization of cyanobacteria [43]. AEG and DAB each have unique retention times and ion ratios [44,46,49] and have been noted to be toxic $[44,46]$. Further research is needed to understand the interactions between these toxins which can co-occur in the same environment as shown here. As stated previously, the MC concentrations reported here represent extractable MCs rather than total MCs (protein-bound plus free MC). The identification of detectable MCs in fish carp liver but not muscle could mean that the carp have a mechanism for detoxifying MCs or storing them in the covalently-bound form as previously documented in sunfish (Lepomis gibbosus) from a New Hampshire lake [50]. These results closely match the results from highly eutrophic lakes in China, which had high concentrations of MCs in three species of carp (Lake Taihu) and higher MC accumulation in the liver as compared to muscle (Lake Chaohu; [51]). Similarly, BMAA was also found in Lake Taihu [52]. Co-occurrence of BMAA and MC have also been noted in Europeon waterbodies [53]. The observed high concentrations of MC in the carp liver are further evidence of toxigenic cyanobacteria in Lake Mascoma.

Although the association of ALS and BMAA exposure does not prove cause and effect, we can at least state that an exposure risk for this toxin to people living in proximity to the lake exists. Cyanobacteria are ubiquitous in water bodies, and multiple species of cyanobacteria appear to be capable of BMAA production in aquatic environments [7]. The examination of other ecosystems has demonstrated the presence of BMAA in fish and crustaceans in the United States, France and Sweden [54-59]. Epidemiological studies of areas of high incidence of ALS have supported the possibility of BMAA being acquired through the aquatic food web. Investigation of the high incidence of ALS in Two Rivers, WI found that ALS patients ate fish from nearby Lake Michigan (a lake known to have cyanobacterial blooms) more frequently than controls [60]. Another region of increased ALS incidence has been noted in the south of France in proximity to the Thau Lagoon where BMAA has been identified in shellfish [54]. The Thau Lagoon, a shallow coastal lagoon off the Mediterranean Sea, is frequently subject to cyanobacterial blooms [54].

An area of growing research and concern is the possibility of airborne cyanotoxins creating an exposure through direct inhalation [43]. It is well documented that other microorganisms such as Karenia brevis [61,62] and Legionella pneumophila [63-66] and the marine organism Pfiesteria piscicida [67] cause human disease through aerosolization. Laboratory studies have shown that cyanotoxins in water can be transferred to air via a bubble-bursting process [68]. Moreover, recreational activities such as waterskiing in waterbodies that experience toxin-producing cyanobacterial blooms have been shown to generate aerosolized cyanotoxin (MC), making chronic inhalation a potential route of exposure [69]. Furthermore, research suggests that airborne cyanotoxins are also of concern in desert environments where the desert surface is stabilized by cyanobacteria-dominated cryptogamic crust [70]. The toxins found in the desert crust in Qatar have been shown to accumulate and persist in the soil leading to the potential for human exposure through particulate matter picked up in desert storms 
or distributed through anthropogenic activities [71]. Thus, there is a potential human health risk through the inhalation of airborne toxins in desert dust. It has been hypothesized that cyanobacterial toxins in airborne desert dust could be responsible for the high rates of ALS among US veterans deployed in the 1990-1991 Persian Gulf War [34]. In more fertile regions, the plowing of agricultural land previously irrigated with cyanobacteria-contaminated irrigation water could also produce airborne dust with human health implications. It is intriguing that the olfactory anatomy is structured so that there is no blood brain barrier in the cribiform plate, perhaps producing a scenario where cyanotoxins might gain easy access to the central nervous system [72].

Epidemiological studies can suggest associations, but do not prove causation; further studies are needed to determine how BMAA is acquired by humans and whether exposure to BMAA is sufficient to cause neurodegeneration. Concerns about possible synergistic effects between BMAA and other cyanotoxins have been noted but have not yet been sufficiently tested. The combination of BMAA, DAB, $\mathrm{AEG}$, and MCs found within the samples presented here, suggest that further research is warranted.

\section{Experimental Section}

\subsection{Fish Tissue Analysis}

A live-caught carp was acquired from Lake Mascoma in 2012. Carp brain samples were extracted in triplicate from different parts of the organ with $0.1 \mathrm{M}$ trichloroacetic acid $(0.5 \mathrm{mg}$ tissue $/ \mu \mathrm{L}$ TCA, Sigma, T6399, St. Louis, MO, USA) using sonication (Fisher Sonic Dismembrator Model 100, Waltham, MA, USA) two times for $30 \mathrm{~s}$ each at $5 \mathrm{Watts}$, followed by a resting period at $4{ }^{\circ} \mathrm{C}$ overnight. The sample was then vortexed and centrifuged (Labnet Spectrafuge, 16M, Edison, NJ, USA) at 13,000 rpm for 3 min. The supernatant was then transferred to a $0.22 \mu \mathrm{m}$ centrifugal filter device (Millipore Ultrafree-MC, Billicore, MA, USA) and centrifuged at 13,000 rpm for $3 \mathrm{~min}$. A second equal volume of TCA was added to the pellets, followed by a second sonication. The samples were left to rest for $1 \mathrm{~h}$ and then vortexed and centrifuged at 13,000 rpm for $3 \mathrm{~min}$. The supernatants were filtered and then pooled and the pellet hydrolyzed in $6.0 \mathrm{M} \mathrm{HCl}\left(0.25 \mathrm{mg}\right.$ tissue/ $\mu \mathrm{L} \mathrm{HCl}, 16 \mathrm{~h}$ at $\left.110^{\circ} \mathrm{C}\right)$. Hydrolyzed samples were dried using a Thermo-Savant SC250DDA Speed Vac Plus (Waltham, MA, USA), and stored at $4{ }^{\circ} \mathrm{C}$ until analyzed [54,58]. The results from the TCA and acid hydrolysis analysis were combined to give a total BMAA concentration (Table 1).

The carp liver and muscle did not undergo a TCA free-amino acid extraction but were sonicated in Direct $\mathrm{Q}$ water (18.2 M $\Omega$, Millipore) followed by acid hydrolysis $(0.06 \mathrm{mg} / \mu \mathrm{L}$ to produce a final $\mathrm{HCl}$ concentration of $6.0 \mathrm{M}$ ). Following acid hydrolysis, the sample was completely dried using a Thermo-Savant SC250DDA Speed Vac Plus (Waltham, MA, USA). The sample was then reconstituted in $0.1 \mathrm{M}$ TCA and the oils were removed using a chloroform extraction (1:1). The TCA phase was dried in a Speed Vac and reconstituted in $20 \mathrm{mM} \mathrm{HCl} \mathrm{(1:20} \mathrm{dilution).} \mathrm{Samples} \mathrm{were} \mathrm{derivatitized} \mathrm{using}$ 6-aminoquinolyl- $N$-hydroxysuccinimidyl carbamate (AQC Waters AccQTag reagent, PN WAT052880, Milford, MA, USA) according to the manufacturer's directions and AQC and Direct-Q water (18 M $\Omega$, Millipore) blanks were inserted between samples as negative analytical controls.

Authenticated standards of BMAA (Irvine Chemistry, Anaheim, CA, USA, compared with Sigma B-107, St. Louis, MO, USA), L-2,4-diaminobutryic acid dihydrochloride (DAB, 32830, Sigma, 
St. Louis, MO, USA), and N-(2-aminoethyl)glycine (AEG, A1153 TCI America, Portland, OR, USA) were analyzed and compared with sample peaks. Samples were analyzed using a triple quadrupole LC-MS/MS instrument (Thermo Scientific Finnigan TSQ Quantum Ultra AM, San Jose, CA, USA) with a HESI-II source. Separation was achieved with an Ultra High Pressure Liquid Chromatography (Waters Acquity-UHPLC, Milford, MA, USA) system with a Binary Solvent Manager, Sample Manager and a Phenomenex Kinetex column (00D-4475-AN, $2.1 \times 100 \mathrm{~mm}, 1.7 \mu, \mathrm{C} 18,100 \AA$ ) at $65^{\circ} \mathrm{C}$. Water (W-6 Optima LC/MS, Fisher Scientific, Waltham, MA, USA) with $0.1 \%(v / v)$ formic acid (28905 Thermo Scientific, Waltham, MA, USA) was used for LC-MS/MS Eluent A. Burdick and Jackson Honeywell $0.1 \%(v / v)$ formic acid in acetonitrile (LC441-2.5) was used for LC-MS/MS Eluent B. The elution gradient and instrument parameters followed the previously reported validated method [54,58]. Product-ion analysis of BMAA used $\mathrm{m} / \mathrm{z} 459$ as the precursor ion for collision-induced dissociation (CID) and $m / z 230$ as a secondary confirmation precursor ion $\left(\mathrm{m} / z 459+2 \mathrm{H}^{+}\right)$. Two-step mass filtering was performed during selective reaction monitoring (SRM) of BMAA after CID in the second quadrupole, monitoring the following transitions: $\mathrm{m} / \mathrm{z}, 459$ to $119, \mathrm{CE} 21 \mathrm{eV} ; \mathrm{m} / \mathrm{z} 459$ to 171 , CE $38 \mathrm{eV}$; $\mathrm{m} / \mathrm{z} 459$ to $188, \mathrm{CE} 38 \mathrm{eV} ; \mathrm{m} / \mathrm{z} 459$ to 214 , CE $35 \mathrm{eV} ; \mathrm{m} / \mathrm{z} 459$ to $258, \mathrm{CE} 21 \mathrm{eV} ; \mathrm{m} / z, 459$ to 289 , $\mathrm{CE} 17 \mathrm{eV}$, and $\mathrm{m} / z 230$ to $171, \mathrm{CE} 27 \mathrm{eV}$. The resultant product ions were detected, after passing the third quadrupole and their relative abundances were quantified.

Detection limits (LOD) and limits of quantification (LOQ) of BMAA and DAB on the LC-MS/MS were determined experimentally using the EPA Method Detection Level (MDL). The MDL for BMAA was 48 femtomoles and 26 femtomoles for DAB. The LOQ was 0.48 picomoles for BMAA and 0.26 picomoles for DAB.

\subsection{Microcystin Preparation and Analysis}

Fish tissue samples ( $0.5 \mathrm{~g}$ wet weight) were placed in a $1.5 \mathrm{~mL}$ microcentrifuge tube and homogenized in the centrifuge tube with a Teflon pestle. Each sample received $0.5 \mathrm{~mL}$ distilled water and was then subjected to three rapid freeze-thaw cycles using a $-70{ }^{\circ} \mathrm{C}$ dry ice-95\% ethanol bath. Samples were vortexed for $30 \mathrm{~s}$ and sonicated for $1 \mathrm{~min}$ after each thaw. Samples were centrifuged at $2000 \times g$ $(6000 \mathrm{rpm})$ to remove the particulate matter and the supernatant was transferred to another $1.5 \mathrm{~mL}$ centrifuge tube and stored frozen $\left(-40^{\circ} \mathrm{C}\right)$ until tested for MC with the ELISA kit (Envirologix Inc., Portland, ME, USA).

ELISA analyses for MCs were performed using the QuantiPlate Kit for Microcystins (EnviroLogix Inc. Portland, ME, USA) with MC standards at 2500, 600 and $160 \mathrm{pg} / \mathrm{mL}$. The 96-wellplate was read (optical densities) on a Bio-Tek EL800 Plate Reader (Winooski, VT, USA) (sensitivity of \pm 0.010 Abs) at a wavelength of $450 \mathrm{~nm}$. MC concentrations were calculated based on a cubic log-log standard curve. Limit of quantification of the kit was $147 \mathrm{pg} / \mathrm{mL}$. Using dilutions of the calibrators to increase sensitivity, the LOQ was reduced to between 50 to $60 \mathrm{pg} / \mathrm{mL}$. The 96-well plate was also read at a dual wavelength of $630 \mathrm{~nm}$ as a reference to remove any interference from bubbles in the sample or scratches on the plate. The MC ELISA used does not provide identification of the microcystin or nodularin variants present. 


\subsection{Aerosol Collection}

Goose Pond and Lake Mascoma aerosol samples were collected during the late summer and early fall of 2008 (both waterbodies of the same water basin with documented cyanobacterial blooms) using a high volume total suspended particulate sampler (TE-5000, Tisch Environmental Inc., Cleves, OH, USA) and 100 micron glass fiber filters. Five filter samples covering four dates were collected over a 24 to $48 \mathrm{~h}$ time period within 3-4.5 $\mathrm{m}$ from the lakeshore.

Samples of air-filter were first examined under the fluorescence microscope for evidence of cyanobacteria. Air filters were then analyzed for $16 \mathrm{~S}$ DNA using $0.5 \mathrm{~cm} \times 0.5 \mathrm{~cm}$ squares cut from the filters haphazardly and incubated with $500 \mu \mathrm{L}$ of lysis buffer (100 mM Tris, $5 \mathrm{mM}$ EDTA, $0.2 \%$ SDS and $200 \mathrm{mM} \mathrm{NaCl}$ ) and $1 \mu \mathrm{g}$ proteinase $\mathrm{K}$ (Sigma, St. Louis, MO, USA) at $55{ }^{\circ} \mathrm{C}$ for $1 \mathrm{~h}$ with gentle shaking. Extractions were vortexed and centrifuged $(5 \mathrm{~min}$ at $10,000 \times g)$ and the supernatants transferred to clean tubes. One volume of phenol/chloroform/isoamyl alcohol was then added, vortexed, and centrifuged. The resulting aqueous layer was transferred to a new tube. One volume of chloroform was added and the suspensions mixed. The samples were centrifuged and the supernatants transferred to clean tubes and $1 / 20$ volume of $5 \mathrm{M} \mathrm{NaCl}$ was added and mixed. Two volumes of ice-cold $95 \%(v / v)$ aqueous ethanol were added and the suspensions mixed. The extracts were then incubated at $-20{ }^{\circ} \mathrm{C}$ for $1 \mathrm{~h}$ before being centrifuged as before. The supernatant was discarded and the tubes were allowed to air dry before the pellets were resuspended in $100 \mu \mathrm{L}$ of MilliQ water for downstream PCR amplification. Custom-made cyanobacterial 16S primers CYA359F and CYA781R were used (Sigma, St. Louis, MO, USA) [73]. The forward primer had a GC clamp attached during synthesis for downstream DGGE application. To each reaction, $25 \mu \mathrm{L}$ of DreamTaq Green PCR Master Mix (proprietary mix of primer and buffer, $0.4 \mathrm{mM}$ oligonucleotides, $4 \mathrm{mM} \mathrm{MgCl}_{2}$ ) (Thermo \# K1082, Waltham, MA, USA), $1 \mu \mathrm{M}$ of forward and reverse primers and $1 \mu \mathrm{g}$ of DNA template were added. Reactions were run in an Arktik Thermal Cycler (Thermo TCA0001, Waltham, MA, USA) on the following protocol: $95{ }^{\circ} \mathrm{C}, 3 \mathrm{~min}, 30 \times$ $\left(94{ }^{\circ} \mathrm{C}, 30 \mathrm{~s}, 56{ }^{\circ} \mathrm{C}, 30 \mathrm{~s}, 72{ }^{\circ} \mathrm{C}, 1 \mathrm{~min}\right)$ and a final extension of $72{ }^{\circ} \mathrm{C}$ for $10 \mathrm{~min}$. Amplicons $(25 \mu \mathrm{L})$ were then run on a $2 \%$ agarose (BioRad) gel prestained with $1 \mathrm{X}$ Gelstar nucleic acid stain (Cambrex Corporation,E. Rutherford, NJ, USA) at $90 \mathrm{~V}$ for $35 \mathrm{~min}$ and visualized with a Leica camera over a $305 \mathrm{~nm}$ UV transilluminator (Fisher FBTI816AQ, Waltham, MA, USA).

An $8 \mathrm{~cm}^{2}$ portion of the air-filter was cut into small pieces and hydrolyzed in $6 \mathrm{M} \mathrm{HCl}$ for $24 \mathrm{~h}$ $\left(110{ }^{\circ} \mathrm{C}\right)$ for BMAA analysis. A portion of the hydrolysate was filtered $(0.22 \mu \mathrm{m}$ centrifugal filter, Millipore UltrafreeMC, Billerica, MA, USA), dried using a Thermo-Savant SC250DDA Speed Vac Plus (Waltham, MA, USA) and resuspended in a minimal amount of DirectQ water (18.2 M $\Omega$, Millipore, Billerica, MA, USA) to concentrate the compounds. The samples were then derivatized using 6-aminoquinolyl- $N$-hydroxysuccinimidyl carbamate (AQC Waters AccQTag reagent, PN WAT052880, Milford, MA, USA) and analyzed as above on a triple quadrupole LC-MS/MS instrument (Thermo Scientific Finnigan TSQ Quantum Ultra AM, San Jose, CA, USA).

A solid phase extraction (SPE) was conducted on two hydrolyzed air filters (Goose Pond 2973-2s and Mascoma Lake \#5). In brief, the filtered, acid hydrolyzed sample was diluted with DirectQ water to a final volume of $10 \mathrm{~mL}$ and loaded onto a two column (Isolute C-18 (1 g) followed by a Phenomenex StrataX X-C (500 mg)) SPE system. The columns were conditioned with $16 \mathrm{~mL}$ of methanol followed by $10 \mathrm{~mL}$ of DirectQ water (Millipore Direct-Q $3 \mathrm{UV}, 18 \mathrm{M} \Omega$ ), and $10 \mathrm{~mL} 0.1 \mathrm{M} \mathrm{HCl}$ respectively. 
After loading the sample, the columns were washed with $10 \mathrm{~mL} 0.1 \mathrm{M} \mathrm{HCl}$ and the effluent discarded. The C-18 cartridge was then removed and the StrataX X-C was washed with $4 \mathrm{~mL}$ methanol followed by $4 \mathrm{~mL} 0.5 \%$ ammonium hyrdoxide/methanol which were also discarded. Ten milliliters of $10 \%$ ammonium hydroxide/methanol were then passed through the column, and the eluate was collected, dried in a rotary evaporator, and the vial washed with $1 \mathrm{~mL}$ of $20 \mathrm{mM} \mathrm{HCl}$ which was split into two equal portions. The reconstituted sample was derivatized without dilution with AQC and analyzed on the Thermo Quantum Ultra AM as described above.

\section{Conclusions}

The cyanobacterial neurotoxin BMAA has been implicated as a possible environmental risk factor or causative agent for ALS/PDC on Guam. We have demonstrated the presence of BMAA in the one sampling of the aquatic food web and in aerosol samples from a lake adjacent to an area of previously documented high ALS incidence. Further studies are needed to confirm the route of toxin exposure and mechanism of pathogenesis.

\section{Acknowledgments}

The authors thank the Hitchcock Foundation, SYNERGY grant support, private donations to the Dartmouth-Hitchcock ALS Center, and ALSA grant support. We thank The Deerbrook Charitable Trust for their support. The authors would also like to thank James Martel for his contributions regarding sample collection. We also acknowledge our courageous and inspiring ALS patients for their support.

\section{Author Contributions}

Sandra Anne Banack developed the methods, conducted the analysis, and interpreted the results for BMAA, DAB, and AEG. She also contributed to the manuscript preparation and completion. Tracie Caller contributed to the experimental design and manuscript preparation. Patricia Henegan wrote parts of the manuscript and coordinated manuscript preparation and submission. James Haney and Amanda Murby collected the airfilters and conducted the MC analysis. James S. Metcalf conducted the microscopy on the air filters and oversaw the DNA analysis. James Powell conducted the DNA analysis. Paul Alan Cox and Elijah Stommel designed the experiments, managed and funded the project, and wrote the manuscript.

\section{Conflicts of Interest}

The authors declare no conflict of interest.

\section{References}

1. Factor-Litvak, P.; Al-Chalabi, A.; Ascherio, A.; Bradley, W.; Chio, A.; Garruto, R.; Hardiman, O.; Kamel, F.; Kasarskis, E.; McKee, A.; et al. Current pathways for epidemiological research in Amyotrophic Lateral Sclerosis. Amyotroph. Lateral Scler. Front. Degener. 2013, 14, 33-43. 
2. Ishimura, R.; Nagy, G.; Dotu, I.; Zhou, H.; Yang, X.L.; Schimmel, P.; Senju, S.; Nishimura, Y.; Chuang, J.H.; Ackerman, S.L. RNA function. Ribosome stalling induced by mutation of a CNS-specific tRNA causes neurodegeneration. Science 2014, 345, 455-459.

3. Pablo, J.; Banack, S.A.; Cox, P.A.; Johnson, T.E.; Papapetropoulos, S.; Bradley, W.G.; Buck, A.; Mash, D.C. Cyanobacterial neurotoxin BMAA in ALS and Alzheimer's Disease. Acta Neurol. Scand. 2009, 120, 216-225.

4. Banack, S.A.; Caller, T.A.; Stommel, E.W. The cyanobacteria derived toxin $\beta$ - $N$-methylamino-Lalanine and Amyotrophic Lateral Sclerosis. Toxins 2010, 2, 2837-2850.

5. Murch, S.J.; Cox, P.A.; Banack, S.A. A mechanism for slow release of biomagnified cyanobacterial neurotoxins and neurodegenerative disease in Guam. Proc. Natl. Acad. Sci. USA 2004, 101, $12228-12231$.

6. Merel, S.; Walker, D.; Chicana, R.; Snyder, S.; Baures, E.; Thomas, O. State of knowledge and concerns on cyanobacterial blooms and cyanotoxins. Environ. Int. 2013, 59, 303-327.

7. Cox, P.A.; Banack, S.A.; Murch, S.J.; Rasmussen, U.; Tien, G.; Bidigare, R.R.; Metcalf, J.S.; Morrison, L.F.; Codd, G.A.; Bergman, B. Diverse taxa of cyanobacteria produce $\beta$ - $N$-methylaminoL-alanine, a neurotoxic amino acid. Proc. Natl. Acad. Sci. USA 2005, 102, 5074-5078.

8. Funari, E.; Testai, E. Human health risk assessment related to cyanotoxins exposure. Crit. Rev. Toxicol. 2008, 38, 97-125.

9. Metcalf, J.S.; Codd, G.A. Cyanotoxins. In Ecology of cyanobacteria II: Their Diversity in Space and Time, 2nd ed.; Whitton, B.A., Ed.; Springer: Dordrecht, The Netherlands, 2012; pp. 651-675.

10. Reed, D.; Plato, C.; Elizan, T.; Kurland, L.T. The amyotrophic lateral sclerosis/parkinsonismdementia complex: A ten-year follow-up on Guam. I. Epidemiologic studies. Am. J. Epidemiol. 1966, 83, 54-73.

11. Arnold, A.; Edgren, D.C.; Palladino, V.S. Amyotrophic lateral sclerosis; fifty cases observed on Guam. J. Nerv. Ment. Dis. 1953, 117, 135-139.

12. Kurland, L.T.; Mulder, D.W. Epidemiologic investigations of amyotrophic lateral sclerosis. I. Preliminary report on geographic distribution and special reference to the Mariana Islands, including clinical and pathologic observations. Neurology 1954, 4, 438-448.

13. Zimmerman, H. Monthly Report to the Medical Officer in Command; United States Navy Medical Research Unit: San Fransisco, CA, USA, 1945.

14. Whiting, M. Toxicity of cycads: A literature review. Econ. Bot. 1963, 17, 270-302.

15. Dastur, D.K. Cycad toxicity in monkeys: Clinical, pathological, and biochemical aspects. Fed. Proc. 1964, 23, 1368-1369.

16. Whiting, M.G. Food practices in ALS foci in Japan, the Marianas, and New Guinea. Fed. Proc. 1964, 23, 1343-1345.

17. Spencer, P.S.; Nunn, P.B.; Hugon, J.; Ludolph, A.; Roy, D.N. Motorneurone disease on Guam: Possible role of a food neurotoxin. Lancet 1986, 1, 965.

18. Banack, S.; Cox, P. Distribution of the neurotoxic non-protein amino acid BMAA in Cycas micronesica. Bot. J. Lin. Soc. 2003, 143, 165-168.

19. Cox, P.A.; Banack, S.A.; Murch, S.J. Biomagnification of cyanobacterial neurotoxins and neurodegenerative disease among the chamorro people of Guam. Proc. Natl. Acad. Sci. USA 2003, $100,13380-13383$. 
20. Vega, A.; Bell, E.A. $\alpha$-amino- $\beta$-methylaminopropionic acid, a new amino acid from seeds of Cycas circinalis. Phytochemistry 1967, 6, 759-762.

21. Kisby, G.E.; Ellison, M.; Spencer, P.S. Content of the neurotoxins cycasin (methylazoxymethanol $\beta$-D-glucoside) and BMAA ( $\beta$ - $N$-methylamino-L-alanine) in cycad flour prepared by Guam Chamorros. Neurology 1992, 42, 1336-1340.

22. Banack, S.A.; Cox, P.A. Biomagnification of cycad neurotoxins in flying foxes: Implications for ALS-PDC in Guam. Neurology 2003, 61, 387-389.

23. Cheng, R.; Banack, S.A. Previous studies underestimate BMAA concentrations in cycad flour. Amyotroph. Lateral Scler. 2009, 10, 41-43.

24. Banack, S.A.; Murch, S.J.; Cox, P.A. Neurotoxic flying foxes as dietary items for the Chamorro people, Marianas Islands. J. Ethnopharmacol. 2006, 106, 97-104.

25. Murch, S.J.; Cox, P.A.; Banack, S.A.; Steele, J.C.; Sacks, O.W. Occurrence of $\beta-N$-methylaminoL-alanine (BMAA) in ALS/PDC patients from Guam. Acta Neurol. Scand. 2004, 110, 267-269.

26. Garruto, R.M.; Yanagihara, R.; Gajdusek, D.C. Disappearance of high-incidence Amyotrophic Lateral Sclerosis and Parkinsonism-Dementia on Guam. Neurology 1985, 35, 193-198.

27. Plato, C.C.; Garruto, R.M.; Galasko, D.; Craig, U.K.; Plato, M.; Gamst, A.; Torres, J.M.; Wiederholt, W. Amyotrophic lateral sclerosis and parkinsonism-dementia complex of Guam: Changing incidence rates during the past 60 years. Am. J. Epidemiol. 2003, 157, 149-157.

28. Cox, P.A.; Sacks, O.W. Cycad neurotoxins, consumption of flying foxes, and ALS-PDC disease in Guam. Neurology 2002, 58, 956-959.

29. Torres, J.; Iriarte, L.L.; Kurland, L.T. Amyotrophic lateral sclerosis among Guamanians in California. Calif. Med. 1957, 86, 385-388.

30. Eldridge, R.; Ryan, E.; Rosario, J.; Brody, J.A. Amyotrophic lateral sclerosis and parkinsonism dementia in a migrant population from Guam. Neurology 1969, 19, 1029-1037.

31. Garruto, R.M.; Gajdusek, C.; Chen, K.M. Amyotrophic Lateral Sclerosis among Chamorro migrants from Guam. Ann. Neurol. 1980, 8, 612-619.

32. Garruto, R.M.; Gajdusek, D.C.; Chen, K.M. Amyotrophic lateral sclerosis and parkinsonism-dementia among filipino migrants to Guam. Ann. Neurol. 1981, 10, 341-350.

33. Horner, R.D. Amyotrophic lateral sclerosis among 1991 Gulf War veterans: Evidence for a time-limited outbreak. Neuroepidemiology 2008, 31, 28-32.

34. Cox, P.A.; Richer, R.; Metcalf, J.S.; Banack, S.A.; Codd, G.A.; Bradley, W.G. Cyanobacteria and BMAA exposure from desert dust: A possible link to sporadic ALS among Gulf War veterans. Amyotroph. Lateral Scler. 2009, 10, 109-117.

35. Haley, R.W. Excess incidence of ALS in young Gulf War veterans. Neurology 2003, 61, 750-756.

36. Horner, R.D.; Kamins, K.G.; Feussner, J.R.; Grambow, S.C.; Hoff-Lindquist, J.; Harati, Y.; Mitsumoto, H.; Pascuzzi, R.; Spencer, P.S.; Tim, R.; et al. Occurrence of amyotrophic lateral sclerosis among Gulf War veterans. Neurology 2003, 61, 742-749.

37. Coffman, C.J.; Horner, R.D.; Grambow, S.C.; Lindquist, J.; Project, V.A.C.S.P. Estimating the occurrence of amyotrophic lateral sclerosis among Gulf War (1990-1991) veterans using capture-recapture methods. Neuroepidemiology 2005, 24, 141-150. 
38. Caller, T.A.; Doolin, J.W.; Haney, J.F.; Murby, A.J.; West, K.G.; Farrar, H.E.; Ball, A.; Harris, B.T.; Stommel, E.W. A cluster of amyotrophic lateral sclerosis in New Hampshire: A possible role for toxic cyanobacteria blooms. Amyotroph. Lateral Scler. 2009, 10, 101-108.

39. Torbick, N.; Hession, S.; Stommel, E.; Caller, T. Mapping amyotrophic lateral sclerosis lake risk factors across northern New England. Int. J. Health Geograph. 2014, 13, doi:10.1186/ 1476-072X-13-1.

40. Downing, S.; Banack, S.A.; Metcalf, J.S.; Cox, P.A.; Downing, T.G. Nitrogen starvation of cyanobacteria results in the production of $\beta-N$-methylamino-L-alanine. Toxicon 2011, 58, 187-194.

41. Crivelli, A. The destruction of aquatic vegetation by carp. Hydrobiologia 1983, 106, 37-41.

42. Gerking, S.D. Chapter 4-Plant-eating fish. In Feeding Ecology of Fish; Gerking, S.D., Ed.; Academic Press: San Diego, CA, USA, 1994; pp. 57-88.

43. Stommel, E.W.; Field, N.C.; Caller, T.A. Aerosolization of cyanobacteria as a risk factor for Amyotrophic Lateral Sclerosis. Med. Hypotheses 2013, 80, 142-145.

44. Banack, S.A.; Downing, T.G.; Spacil, Z.; Purdie, E.L.; Metcalf, J.S.; Downing, S.; Esterhuizen, M.; Codd, G.A.; Cox, P.A. Distinguishing the cyanobacterial neurotoxin $\beta$ - $N$-methylamino-L-alanine (BMAA) from its structural isomer 2,4-diaminobutyric acid (2,4-DAB). Toxicon 2010, 56, 868-879.

45. Banack, S.A.; Metcalf, J.S.; Jiang, L.; Craighead, D.; Ilag, L.L.; Cox, P.A. Cyanobacteria produce $N$-(2-aminoethyl)glycine, a backbone for peptide nucleic acids which may have been the first genetic molecules for life on earth. PLoS One 2012, 7, e49043.

46. Metcalf, J.S.; Banack, S.A.; Richer, R.; Cox, P.A. Neurotoxic amino acids and their isomers in desert environments. J. Arid Environ. 2015, 112B, 140-144.

47. Haney, J. University of New Hampshire, Durham, NH, USA. Unpublished work, 2014.

48. Jiang, L.; Eriksson, J.; Lage, S.; Jonasson, S.; Shams, S.; Mehine, M.; Ilag, L.L.; Rasmussen, U. Diatoms: A novel source for the neurotoxin BMAA in aquatic environments. PLoS One 2014, 9, e84578.

49. Banack, S.A.; Metcalf, J.S.; Spacil, Z.; Downing, T.G.; Downing, S.; Long, A.; Nunn, P.B.; Cox, P.A. Distinguishing the cyanobacterial neurotoxin $\beta-N$-methylamino-L-alanine (BMAA) from other diamino acids. Toxicon 2011, 57, 730-738.

50. Smith, J.L.; Haney, J.F. Foodweb transfer, accumulation, and depuration of microcystins, a cyanobacterial toxin, in pumpkinseed sunfish (Lepomis gibbosus). Toxicon 2006, 48, 580-589.

51. Xie, L.; Xie, P.; Guo, L.; Li, L.; Miyabara, Y.; Park, H.D. Organ distribution and bioaccumulation of microcystins in freshwater fish at different trophic levels from the eutrophic Lake Chaohu, China. Environ. Toxicol. 2005, 20, 293-300.

52. Jiao, Y.; Chen, Q.; Chen, X.; Wang, X.; Liao, X.; Jiang, L.; Wu, J.; Yang, L. Occurrence and transfer of a cyanobacterial neurotoxin $\beta-N$-methylamino-L-alanine within the aquatic food webs of gonghu bay (Lake Taihu, China) to evaluate the potential human health risk. Sci. Total Environ. 2014, 468-469, 457-463.

53. Metcalf, J.S.; Banack, S.A.; Lindsay, J.; Morrison, L.F.; Cox, P.A.; Codd, G.A. Co-occurrence of $\beta$ - $N$-methylamino-L-alanine, a neurotoxic amino acid with other cyanotoxins in British waterbodies, 1990-2004. Environ. Microbiol. 2008, 10, 702-708. 
54. Masseret, E.; Banack, S.; Boumediene, F.; Abadie, E.; Brient, L.; Pernet, F.; Juntas-Morales, R.; Pageot, N.; Metcalf, J.; Cox, P.; et al. Dietary BMAA exposure in an Amyotrophic Lateral Sclerosis cluster from Southern France. PLoS One 2013, 8, e83406.

55. Brand, L.E.; Pablo, J.; Compton, A.; Hammerschlag, N.; Mash, D.C. Cyanobacterial blooms and the occurrence of the neurotoxin $\beta$ - $N$-methylamino-L-alanine (BMAA) in south Florida aquatic food webs. Harmful Algae 2010, 9, 620-635.

56. Mondo, K.; Hammerschlag, N.; Basile, M.; Pablo, J.; Banack, S.A.; Mash, D.C. Cyanobacterial neurotoxin $\beta-N$-methylamino-L-alanine (BMAA) in shark fins. Mar. Drugs 2012, 10, 509-520.

57. Jonasson, S.; Eriksson, J.; Berntzon, L.; Spacil, Z.; Ilag, L.L.; Ronnevi, L.O.; Rasmussen, U.; Bergman, B. Transfer of a cyanobacterial neurotoxin within a temperate aquatic ecosystem suggests pathways for human exposure. Proc. Natl. Acad. Sci. USA 2010, 107, 9252-9257.

58. Banack, S.A.; Metcalf, J.S.; Bradley, W.G.; Cox, P.A. Detection of cyanobacterial neurotoxin $\beta$ - $N$-methylamino-L-alanine within shellfish in the diet of an ALS patient in florida. Toxicon 2014, 90, 167-173.

59. Field, N.C.; Metcalf, J.S.; Caller, T.A.; Banack, S.A.; Cox, P.A.; Stommel, E.W. Linking $\beta$-methylamino-L-alanine exposure to sporadic Amyotrophic Lateral Sclerosis in Annapolis, MD. Toxicon 2013, 70C, 179-183.

60. Sienko, D.G.; Davis, J.P.; Taylor, J.A.; Brooks, B.R. Amyotrophic lateral sclerosis. A case-control study following detection of a cluster in a small wisconsin community. Arch. Neurol. 1990, 47, $38-41$.

61. Fleming, L.E.; Kirkpatrick, B.; Backer, L.C.; Bean, J.A.; Wanner, A.; Reich, A.; Zaias, J.; Cheng, Y.S.; Pierce, R.; Naar, J.; et al. Aerosolized red-tide toxins (brevetoxins) and asthma. Chest 2007, 131, 187-194.

62. Fleming, L.E.; Bean, J.A.; Kirkpatrick, B.; Cheng, Y.S.; Pierce, R.; Naar, J.; Nierenberg, K.; Backer, L.C.; Wanner, A.; Reich, A.; et al. Exposure and effect assessment of aerosolized red tide toxins (brevetoxins) and asthma. Environ. Health Perspect. 2009, 117, 1095-1100.

63. Dondero, T.J., Jr.; Rendtorff, R.C.; Mallison, G.F.; Weeks, R.M.; Levy, J.S.; Wong, E.W.; Schaffner, W. An outbreak of legionnaires' disease associated with a contaminated air-conditioning cooling tower. N. Engl. J. Med. 1980, 302, 365-370.

64. Nygard, K.; Werner-Johansen, O.; Ronsen, S.; Caugant, D.A.; Simonsen, O.; Kanestrom, A.; Ask, E.; Ringstad, J.; Odegard, R.; Jensen, T.; et al. An outbreak of legionnaires disease caused by long-distance spread from an industrial air scrubber in sarpsborg, norway. Clin. Infect. Dis. 2008, 46, 61-69.

65. Den Boer, J.W.; Yzerman, E.; van Belkum, A.; Vlaspolder, F.; van Breukelen, F.J. Legionnaire's disease and saunas. Lancet 1998, 351, 114.

66. Den Boer, J.W.; Yzerman, E.P.; Schellekens, J.; Lettinga, K.D.; Boshuizen, H.C.; van Steenbergen, J.E.; Bosman, A.; van den Hof, S.; van Vliet, H.A.; Peeters, M.F.; et al. A large outbreak of legionnaires' disease at a flower show, the netherlands, 1999. Emerg. Infect. Dis. 2002, 8, 37-43.

67. Morris, J.G., Jr. Pfiesteria, “The cell from hell”, and other toxic algal nightmares. Clin. Infect. Dis. 1999, 28, 1191-1196. 
68. Cheng, Y.S.; Zhou, Y.; Irvin, C.M.; Kirkpatrick, B.; Backer, L.C. Characterization of aerosols containing microcystin. Mar. Drugs 2007, 5, 136-150.

69. Sharma, N.K.; Singh, S. Differential aerosolization of algal and cyanobacterial particles in the atmosphere. Indian J. Microbiol. 2010, 50, 468-473.

70. Powell, J.T.; Chatziefthimiou, A.D.; Banack, S.A.; Cox, P.A.; Metcalf, J.S. Desert crust microorganisms, their environment, and human health. J. Arid Environ. 2015, 112B, 127-133.

71. Richer, R.; Banack, S.A.; Metcalf, J.S.; Cox, P.A. The persistence of cyanobacterial toxins in desert soils. J. Arid Environ. 2015, 112B, 134-139.

72. Danielyan, L.; Schäfer, R.; von Ameln-Mayerhofer, A.; Buadze, M.; Geisler, J.; Klopfer, T.; Burkhardt, U.; Proksch, B.; Verleysdonk, S.; Ayturan, M.; et al. Intranasal delivery of cells to the brain. Eur. J. Cell Biol. 2009, 88, 315-324.

73. Boutte, C.; Grubisic, S.; Balthasart, P.; Wilmotte, A. Testing of primers for the study of cyanobacterial molecular diversity by dgge. J. Microbiol. Methods 2006, 65, 542-550.

(C) 2015 by the authors; licensee MDPI, Basel, Switzerland. This article is an open access article distributed under the terms and conditions of the Creative Commons Attribution license (http://creativecommons.org/licenses/by/4.0/). 